\title{
Soil redistribution and weathering controlling the fate of geochemical and physical carbon stabilization mechanisms in soils of an eroding landscape
}

\author{
S. Doetterl ${ }^{1,4}$, J.-T. Cornelis ${ }^{2,5}$, J. Six ${ }^{3}$, S. Bodé ${ }^{1}$, S. Opfergelt ${ }^{2}$, P. Boeckx ${ }^{1}$, and K. Van Oost ${ }^{4}$ \\ ${ }^{1}$ Department of Applied Analytical and Physical Chemistry, Ghent University, Coupure Links 653, 9000 Gent, Belgium \\ ${ }^{2}$ Environmental Sciences, Earth \& Life Institute, Université catholique de Louvain, Croix du Sud 2, \\ 1348 Louvain-la-Neuve, Belgium \\ ${ }^{3}$ Department of Environmental Systems Science, Swiss Federal Institute of Technology, ETH Zurich, \\ Tannenstrasse 1, 8092 Zurich, Switzerland \\ ${ }^{4}$ George Lemaître Centre for Earth and Climate Research, Earth \& Life Institute, Université catholique \\ de Louvain, Place Louis Pasteur 3, 1348 Louvain-la-Neuve, Belgium \\ ${ }^{5}$ Biosystem Engineering Department, Gembloux Agro-Bio Tech, University of Liège, Passage des Déportés 2,5030 \\ Gembloux, Belgium
}

Correspondence to: S. Doetterl (sebastian.doetterl@ugent.be)

Received: 19 September 2014 - Published in Biogeosciences Discuss.: 26 November 2014

Revised: 27 January 2015 - Accepted: 29 January 2015 - Published: 4 March 2015

\begin{abstract}
The role of eroding landscapes in organic carbon stabilization operating as $\mathrm{C}$ sinks or sources has been frequently discussed, but the underlying mechanisms are not fully understood. Our analysis aims to clarify the effects of soil redistribution on physical and biogeochemical soil organic carbon (SOC) stabilization mechanisms along a hillslope transect. The observed mineralogical differences seem partly responsible for the effectiveness of geochemical and physical SOC stabilization mechanisms as the mineral environment along the transect is highly variable and dynamic. The abundance of primary and secondary minerals and the weathering status of the investigated soils differ drastically along this transect. Extractable iron and aluminum components are generally abundant in aggregates, but show no strong correlation to SOC, indicating their importance for aggregate stability but not for SOC retention. We further show that pyrophosphate extractable soil components, especially manganese, play a role in stabilizing SOC within non-aggregated mineral fractions. The abundance of microbial residues and measured ${ }^{14} \mathrm{C}$ ages for aggregated and nonaggregated SOC fractions demonstrate the importance of the combined effect of geochemical and physical protection to stabilize SOC after burial at the depositional site. Mineral
\end{abstract}

alteration and the breakdown of aggregates limit the protection of $\mathrm{C}$ by minerals and within aggregates temporally. The ${ }^{14} \mathrm{C}$ ages of buried soil indicate that $\mathrm{C}$ in aggregated fractions seems to be preserved more efficiently while $\mathrm{C}$ in nonaggregated fractions is released, allowing a re-sequestration of younger $\mathrm{C}$ with this fraction. Old ${ }^{14} \mathrm{C}$ ages and at the same time high contents of microbial residues in aggregates suggest either that microorganisms feed on old carbon to build up microbial biomass or that these environments consisting of considerable amounts of old $\mathrm{C}$ are proper habitats for microorganisms and preserve their residues. Due to continuous soil weathering and, hence, weakening of protection mechanisms, a potential $\mathrm{C}$ sink through soil burial is finally temporally limited.

\section{Introduction}

Soil organic carbon (SOC) is one of the most important terrestrial C pools. Carbon in soils can be protected against decomposition by three key mechanisms: (i) inherent biochemical recalcitrance; (ii) organo-mineral associations, by interaction of organic molecules with mineral surfaces; and 
(iii) physical protection, making the $\mathrm{SOC}$ inaccessible to degraders/consumers within soil aggregates (Sollins et al., 1996; Six et al., 2002). These mechanisms are interactive (e.g., aggregation of organo-mineral associations could already include biochemically recalcitrant SOC) and their contribution to SOC stabilization is strongly influenced by soil environmental conditions and landform (Salomé et al., 2010; Berhe et al., 2012; Dungait et al., 2012; X. Wang et al., 2014). Distinguishing the role of a single mechanism for stabilizing $\mathrm{C}$ is, hence, a difficult task and a matter of ongoing debate and research (Berhe et al., 2012). For example, some authors argue that the biochemical recalcitrance of organic molecules does not exist per se and has always to be seen in an environmental context (Kleber, 2010), while others argue that "recalcitrant SOM [soil organic matter] can be defined by intrinsic molecular properties, but these properties may be fairly irrelevant under specific environmental conditions" (von Luetzow and Koegel-Knabner, 2010).

Studying SOC dynamics in landscapes with lateral soil fluxes requires the combined study of geomorphological, climatic, biogeochemical, and microbial parameters (Park et al., 2014). In most studies on SOC dynamics, the landscapes in which $\mathrm{C}$ exchange takes place are stable surfaces with no or little lateral fluxes of soil or C. Hence, SOC fluxes in complex pool models are limited to a vertical exchange between soil and atmosphere. Connecting the different controls on SOC dynamics across soil depths and topographic positions has only recently received attention in landscape scale studies on SOC dynamics (Berhe et al., 2012; Doetterl et al., 2012). Bringing the detailed knowledge that we possess about SOC dynamics at plot scales and micro-scales into perspective at the landscape scale remains largely neglected. Recently, soil redistribution in cropland and grassland systems has been shown to lead to distinct qualitative and quantitative SOC modifications along geomorphic gradients compared to soils in stable landforms (Yoo et al., 2006; Dlugoss et al., 2011; Berhe et al., 2012). Soils at eroding sites are usually $C$ depleted while soils in depositional settings can store more SOC due to burial of topsoil with eroded sediment, potentially storing $\mathrm{C}$ for centuries (Van Oost et al., 2012; Hoffmann et al., 2013; Johnson, 2014). The removal of weathered topsoil material from eroding positions, the replacement of eroded SOC, and its burial at depositional sites can potentially lead to a net sink for atmospheric $\mathrm{C}$ depending on the fate of the eroded SOC (Harden et al., 1999; Doetterl et al., 2012; Wiaux et al., 2014a). SOC at the depositional site is often regarded as more stable with longer turnover times, depending on microbial activity, environmental conditions (Wang et al., 2013), and biogeochemical characteristics of the transported $\mathrm{C}$ fractions. However, areas (or landscapes) with a fast burial can lead to the accumulation (storage) of labile SOC, which is still vulnerable to decomposition if the conditions at the site of burial change (Wiaux et al., 2014b). Thus, there is an ongoing discussion about depositional sites of highly dynamic landscapes as $\mathrm{C}$ sink or source.
Soil properties with relation to $\mathrm{C}$ stability, such as aggregate stability, availability of reactive mineral surfaces or soil water saturation, differ strongly between stable and dynamic landscapes, i.e., landscapes where high rates of soil redistribution take place. This may have consequences for SOC sequestration and stabilization in soils and requires the use of proxies to investigate the stability of specific fractions. For example, the abundance of amino sugars (AS) and the ${ }^{14} \mathrm{C}$ derived age of a fraction can indicate the potential of a specific mechanism to protect SOC against further degradation. The large majority (>99\%) of AS found in soils are considered to be of microbial origin and constitute an important building block in cell walls and extracellular polysaccharides (Glaser et al., 2004; Glaser and Gross, 2005; Simpson, 2004). In soils, only glucosamine (GluN), galactosamine (GalN), and muramic acid are found in quantifiable concentrations. AS provide a generally readily available energy source for microorganisms and are easy to decompose compared to more recalcitrant organic matter such as lignin or lipids (Amelung et al., 2001, 2008; von Luetzow et al., 2006; Roberts et al., 2007; Schmidt et al., 2011). AS turnover is, therefore, fast compared to other stabilized SOC fractions. Turnover times of AS, however, are strongly affected by interactions with the soil mineral matrix and the soil environment (Bodé, 2013) and this can lead to an accumulation of AS after cell death in soils (Guggenberger et al., 1999; Glaser et al., 2004). This fact can be used to investigate the effectiveness of different stabilization mechanisms. During the transport of sediment to and accumulation and burial at the site of deposition, easily available SOC fractions have been decomposed. However, at the depositional site, subsoil $\mathrm{C}$ is at least partly derived from buried topsoil C. Hence, at the depositional site changes in the abundance of AS and the ${ }^{14} \mathrm{C}$ derived age of a fraction can indicate the potential of a specific mechanism to protect SOC against further degradation (Z. Wang et al., 2014).

Our work is a conceptual approach to analyze and illustrate the mechanisms of soil redistribution effects on $\mathrm{C}$ dynamics. For our study, we hypothesize that the soil redistribution history of a soil profile influences the present weathering status of the soil material, and is therefore a primary control on the abundance and composition of the reactive soil mineral phase, stabilizing SOC through geochemical (association of organic molecules with minerals) and physical (aggregation) mechanisms. To complement our analysis on the importance of different mechanisms to stabilize $\mathrm{C}$ along a geomorphic transect, we measured the ${ }^{14} \mathrm{C}$ and the abundance of microbial residues in the form of AS in the different soil fractions. We further hypothesize that with ongoing soil redistribution, the reactive soil mineral phase will be highly variable, i.e., horizontally in space along the slope transect, vertically with soil depth, and in time due to removal or burial of soil. We use the total reserve in base cations (TRB in $\mathrm{cmol}_{\mathrm{c}} \mathrm{kg}^{-1}$ ) to characterize the weathering status of the soils along the geomorphic transect and complement this with a qualitative and 
Table 1. Key soil and geomorphological properties and identified SOC fractions as described by Doetterl et al. (2012) and Z. Wang et al. (2014) for the investigated soils at different slope positions and soil depths.

\begin{tabular}{|c|c|c|c|c|c|c|c|c|c|c|}
\hline Parameter & Units/Fraction & \multicolumn{3}{|c|}{$\begin{array}{l}\text { Stable } \\
\text { plateau }\end{array}$} & \multicolumn{3}{|c|}{$\begin{array}{l}\text { Eroding } \\
\text { slope }\end{array}$} & \multicolumn{3}{|c|}{$\begin{array}{l}\text { Depositional } \\
\text { footslope }\end{array}$} \\
\hline Slope & {$[\%]$} & & 3 & & & 10 & & & 4 & \\
\hline Total erosion $(-)$ \& deposition $(+)$ & {$[\mathrm{cm}]$} & & 0 & & & -200 & & & 350 & \\
\hline Current erosion \& deposition rate & {$\left[\mathrm{mm} \mathrm{yr}^{-1}\right]$} & & 0 & & & -1.32 & & & 1.16 & \\
\hline Depth & {$[\mathrm{cm}]$} & $0-15$ & $35-50$ & $55-70$ & $0-15$ & $35-50$ & $55-70$ & $0-15$ & $35-50$ & $55-70$ \\
\hline Bulk density & {$\left[\mathrm{g} \mathrm{cm}^{-3}\right]$} & 1.58 & 1.56 & 1.59 & 1.52 & 1.63 & 1.51 & 1.55 & 1.64 & 1.58 \\
\hline $\mathrm{pH}$ & & 7.0 & 7.1 & 7.0 & 7.2 & 7.3 & 7.1 & 6.8 & 6.8 & 6.9 \\
\hline \multirow{4}{*}{$\begin{array}{l}\mathrm{SOC} \\
\left(\mathrm{g} \mathrm{kg}^{-1}\right)\end{array}$} & Bulk soil & 9.6 & 2.6 & 2.4 & 9.3 & 2.1 & 2.1 & 11.6 & 6.7 & 3.9 \\
\hline & Macroaggregate & 14.3 & 3.0 & 4.1 & 12.1 & 3.0 & 5.2 & 14.3 & 7.8 & 6.3 \\
\hline & Microaggregate & 7.3 & 2.6 & 2.2 & 7.3 & 2.8 & 2.4 & 9.3 & 5.9 & 3.5 \\
\hline & Non-aggregated silt + clay & 8.4 & 2.3 & 2.0 & 7.5 & 1.7 & 1.6 & 9.1 & 6.7 & 3.1 \\
\hline \multirow{3}{*}{$\begin{array}{l}\text { Relative } \mathrm{C} \\
\left(\%_{\text {bulk SOC }}\right)\end{array}$} & Macroaggregate & 48 & 19 & 24 & 46 & 19 & 27 & 58 & 37 & 35 \\
\hline & Microaggregate & 35 & 48 & 47 & 24 & 34 & 24 & 21 & 37 & 21 \\
\hline & Non-aggregated silt + clay & 17 & 33 & 29 & 30 & 47 & 49 & 21 & 26 & 44 \\
\hline \multirow{4}{*}{$\begin{array}{l}\text { C stock } \\
\left(\mathrm{gC} \mathrm{m}^{-2} \mathrm{~cm}_{\mathrm{depth}}^{-1}\right)\end{array}$} & Bulk soil & 152 & 41 & 38 & 141 & 34 & 32 & 180 & 110 & 62 \\
\hline & Macroaggregate & 72 & 8 & 9 & 63 & 7 & 9 & 105 & 40 & 22 \\
\hline & Microaggregate & 54 & 19 & 18 & 33 & 12 & 8 & 37 & 40 & 13 \\
\hline & Non-aggregated silt + clay & 26 & 13 & 11 & 41 & 16 & 16 & 39 & 29 & 27 \\
\hline
\end{tabular}

quantitative analysis of clay minerals. If changes in the mineralogical composition of the investigated soils due to soil redistribution occur at a faster pace than weathering-related changes, distinct mineralogical differences between profiles along the slope should be identifiable.

\section{Material and methods}

\subsection{Study site and sampling}

We performed our analysis on nine bulk soil samples and the dominating soil $\mathrm{C}$ fractions that were collected in the study of Doetterl et al. (2012; Table 1) from a geomorphic transect on cropland situated in central Belgium $\left(50^{\circ} 45^{\prime} 41.50^{\prime \prime} \mathrm{N}\right.$; $4^{\circ} 44^{\prime} 07.36^{\prime \prime}$ E) with a south/southeast facing slope. The study area is characterized by a smooth rolling topography with plateaus, slopes (up to $20 \%$ slope) and dry valley bottoms. The climate of the region is a temperate oceanic climate with mild winters and cool summers (Köppen climate $\mathrm{Cfb}, 821 \mathrm{~mm} \mathrm{yr}^{-1} ; 9.7^{\circ} \mathrm{C}$ on 30 -year average; IRM, 2011). The geological substrate is a several meters thick Pleistocene aeolian deposit of calcareous loess, in which Luvisols have developed and are overlaying Tertiary sands (Wouters and Vandenberghe, 1994). Soils are well drained and show no evidence of long-lasting hydromorphic conditions. First traces of agriculture in the region date back to the Late Bronze/Iron Age and both sites have been under continuous agricultural land use since at least 1770 (Rommens et al., 2005; Lannoo, 2009). No detailed information about the long-term (i.e., several centuries) crop rotation or SOC input is available. However, this study focuses on the relative differences between geomorphic positions that were managed in the same way. Soil samples were taken from a stable, non-eroding profile at the hilltop plateau, an eroding profile from the hillslope shoulder ( $200 \mathrm{~cm}$ soil loss), and a depositional profile in the colluvial valley bottom ( $350 \mathrm{~cm}$ soil gain). In order to quantify the vertical and horizontal distribution of SOC fractions, the soil cores were cut into the following depth intervals: the topsoil $(0-15 \mathrm{~cm})$, the shallow subsoil $(35-50 \mathrm{~cm})$, and the deeper subsoil $(55-70 \mathrm{~cm})$.

\subsection{SOC fractionation}

The SOC content was measured in duplicate on $1 \mathrm{~g}$ ground soil subsamples using a VarioMax CN dry combustion analyzer (Elementar $\mathrm{GmbH}$, Germany) with a measuring range of $0.2-400 \mathrm{mg} \mathrm{Cg} \mathrm{soil}^{-1}$ (absolute $\mathrm{C}$ in sample) and a reproducibility of $<0.5 \%$ (relative deviation) on powdered soil samples. To derive functional SOC fractions, Doetterl et al. (2012) used a method based on the conceptual SOC fraction model proposed by Six et al. (1998, 2002; Fig. 1). For details on the gathered fractions see the original study (Doetterl et al., 2012) and the concepts of Six et al. (1998, 2002). In short, the scheme consists of a series of chemical and physical fractionation techniques applied to isolate functional SOC fractions, differentiated by stabilization mechanisms (chemical, biochemical and physical) which can also be associated with different (potential) turnover times (see also von Luetzow et al., 2006). Background information to the key soil and geomorphological properties as well as the abundance and composition of identified SOC fractions as described by Doetterl et al. (2012) and Z. Wang et al. (2014) 


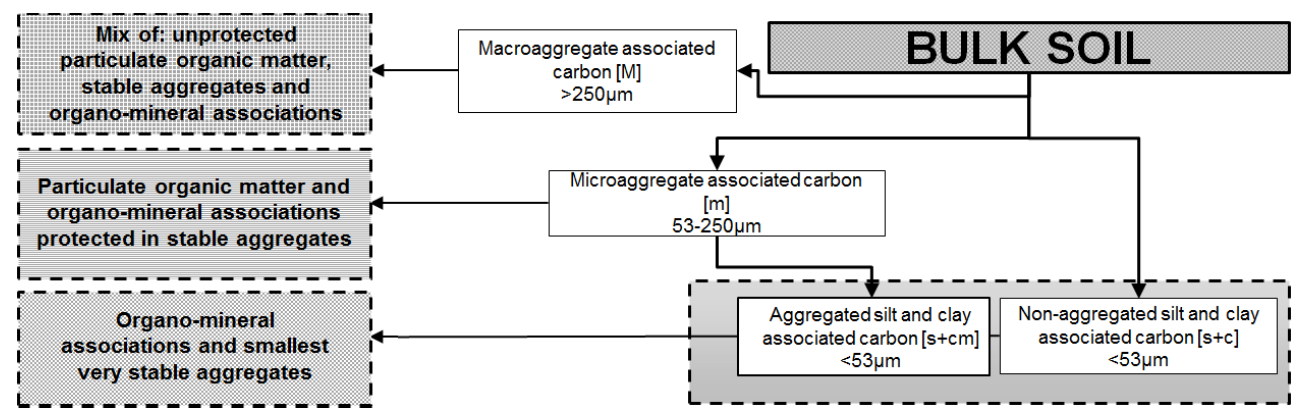

Figure 1. The resulting fractions of the applied fractionation scheme and interpretation of the present carbon stabilization mechanisms in each fraction.

for the investigated soils can be found in Table 1. For our analysis on the microbial composition and ${ }^{14} \mathrm{C}$ age of the fractions we analyzed the environment in which $\mathrm{C}$ is stabilized, hence analyzing macroaggregates and microaggregates as a whole. For the mineralogical analysis we are focusing on comparable fractions, hence comparing aggregated and nonaggregated silt and clay fractions.

\subsection{Soil physico-chemical characterization}

Soil $\mathrm{pH}$ values were determined as the mean of two measurements per sample after a response time of $30 \mathrm{~min}$ and $24 \mathrm{~h}$ respectively in a $1: 2.5$ soil / solution ratio in $25 \mathrm{~mL} 0.01$ $\mathrm{M} \mathrm{CaCl}_{2}$ potentiometrically with a glass electrode using a portable multiparameter Meter HI9828 (Hanna Instruments US Inc., USA). All samples have shown no reaction when treated with $10 \% \mathrm{HCl}$ and are considered free of carbonates.

The soil weathering degree in the different soil depth layers was estimated by measuring the total reserve in bases (TRB, the sum of total content in $\mathrm{Ca}, \mathrm{Na}, \mathrm{K}, \mathrm{Mg}$, in $\mathrm{cmol}_{\mathrm{c}} \mathrm{kg}^{-1}$ ) following Herbillon et al. (1988). The TRB can be used to compare soil horizons relative to the parent material to evaluate the weathering degree of soil material by assessing the relative loss of $\mathrm{Ca}, \mathrm{Na}, \mathrm{K}$, and $\mathrm{Mg}$ cations during weathering. Total elemental content was determined by inductively coupled plasma-atomic emission spectrometry (ICP-AES) on the bulk soil of the three profiles and three depths and the parent loess material after borate fusion (Chao and Sanzolone, 1992).

A three-step sequential extraction scheme of pedogenic organo-mineral associations and oxy-hydroxides (Stucki et al., 1988) was carried out in duplicate in the following order: sodium-pyrophosphate at pH 10 (Bascomb, 1968), ammonium oxalate-oxalic acid at pH 3 (Dahlgren, 1994), and dithionite-citrate-bicarbonate (DCB) at $\mathrm{pH} 8$ (Mehra and Jackson, 1960). This allows assessing the amount of Mn-, $\mathrm{Mg}$-, $\mathrm{Fe}-$, and Al-bearing phases in the different fractions and their correlation with organic $\mathrm{C}$ in the different SOC fractions. The specific extraction was performed on the bulk soil of each sampling position, the (micro)aggregated $(\mathrm{s}+\mathrm{cm})$ and non-aggregated $(\mathrm{s}+\mathrm{c})$ silt and clay associated SOC frac- tions separately. The last two of these were identified as the key fractions to change in their abundance along the hillslope between eroding and depositional (sub-)soils (Doetterl et al., 2012) and are the building blocks for larger aggregates. Each extract was analyzed for its $\mathrm{Al}, \mathrm{Fe}, \mathrm{Mg}$, and $\mathrm{Mn}$ content by ICP-AES.

In our sequential extraction, pyrophosphate $(p)$ extractable components are interpreted as predominantly organically complexed metals. Oxalate $(o)$ extractable components reflect the amorphous secondary $\mathrm{Fe}$ and $\mathrm{Mn}$ oxides and poorly crystalline aluminosilicates (imogolite-type materials, ITM). Dithionite $(d)$ extractable components included predominantly crystalline oxy-hydroxides of Mn, $\mathrm{Mg}, \mathrm{Fe}$, and Al. Several authors could show that pyrophosphate extractable Al may not be attributable only to $\mathrm{Al}$ bound to organo-metallic complexes since the alkaline extractant could also extract $\mathrm{Al}$ from $\mathrm{Al}$ hydroxide phases and from poorly crystalline aluminosilicates (i.e., Schuppli et al., 1983; Kaiser and Zech, 1996). The results of the pyrophosphate extraction must, therefore, be treated with caution due to uncertainty about the origin of the extracted minerals. Hence, we limit our analysis to interpreting the abundance and spatial patterns of the various extractable components in the bulk soil and the SOC fractions and discuss the pedological implications of the observed carbon/mineral correlations.

\subsection{Soil mineralogy}

The mineralogy of the clay-sized fraction was determined by $X$ ray diffraction (XRD, $\mathrm{Cu} \mathrm{K} \alpha, \mathrm{D} 8$, Brucker Advance) after $\mathrm{K}^{+}$and $\mathrm{Mg}^{2+}$ saturation, ethylene glycol solvation, and thermal treatments at 300 and $550^{\circ} \mathrm{C}$ (Robert and Tessier, 1974). Clay minerals were classified and peak-identified according to Brindley and Brown (1980). Quantitative analyses were performed using the Rietveld method through the software package Siroquant V4.0. Refinement of Rietveld parameters was carried out following the instructions provided in the "Siroquant V4.0 Technical and Clay Manuals" until a chi-square value $<3$ was obtained. Key primary minerals that can interfere with the spectra (quartz) and act as sources for clay formation such as amphiboles (hornblende), feldspars 
(albite, orthoclase, plagioclase), mica (muscovite, phengite, biotite) as well as olivine and pyroxene have been quantified in order to analyze their relative abundance in relation to the secondary aluminosilicates. For the latter, we focused on the identification of expandable $2: 1$ layered minerals such as smectite and vermiculite, the non-expandable $2: 1$ layered illite and chlorite and the non-expandable $1: 1$ layered kaolinite. Note that no distinction has been made between primary and secondary chlorite. In a final step, the quantified primary and secondary minerals were then compared along the geomorphic gradient, i.e., soil layers from the same depth across different positions or soil layers from different depths but the same profile, to find relevant trends.

\subsection{Compound-specific analysis of AS}

AS concentrations were determined using liquid chromatography for the bulk soil, macroaggregates ( $>250 \mu \mathrm{m})$, and microaggregates $(53-250 \mu \mathrm{m})$ as well as for the non-aggregated silt and clay fractions $(<53 \mu \mathrm{m})$. Each sample was extracted in duplicate. AS extraction and analysis were based on the procedure described by Bodé et al. (2009). Briefly, samples corresponding to $0.3 \mathrm{mg}$ of $\mathrm{N}$ were successively hydrolyzed with $6 \mathrm{M} \mathrm{HCl}\left(20 \mathrm{~mL} \mathrm{~g}^{-1}\right.$ of sample) at $105^{\circ} \mathrm{C}$ for $8 \mathrm{~h}$ after which AS were purified on a cationic exchange resin (AG50W-X8, 100-200 Mesh, Hydrogen form, Bio-Rad lab.) and eluted by protons prior to liquid chromatographyisotope ratio mass spectrometry (LC-IRMS) analysis. The chromatographic separation was performed using an LC pump (Surveyor MS-Pump Plus, Thermo Scientific, Bremen, Germany) mounted with a PA20 CarboPac analytical anionexchange column $(3 \times 150 \mathrm{~mm}, 6.5 \mu \mathrm{m})$ and a PA20 guard column (Thermo Scientific, Bremen, Germany). Basic AS (GluN and GalN) were eluted with $2 \mathrm{mM} \mathrm{NaOH}$ and a column temperature of $15^{\circ} \mathrm{C}$. An analysis of the repeatability between replicates shows deviations of ca. $11 \%$ between the replicates for GalN with contents of $>100 \mu \mathrm{g} \mathrm{GalN} \mathrm{g} \mathrm{soil}{ }^{-1}$. For smaller values, deviations were higher (ca. $31 \%$ ). For GluN with contents of $>250 \mu \mathrm{g} \mathrm{GluN} \mathrm{g} \mathrm{soil}{ }^{-1}$ deviations of c. $12 \%$ were observed, whereas smaller values differed about $40 \%$ between replicates. Hence, we limit our analysis of this data to observations that exceed the abovementioned uncertainty and to a description of trends within the data set.

\subsection{Isotopic composition and ${ }^{14} \mathrm{C}$ age}

Using ${ }^{14} \mathrm{C}$ radiocarbon dating we estimate the age of the organic material associated with the macroaggregates, microaggregates and the non-aggregated silt and clay fractions at the depositional site in order to see relative differences between fractions and burial depths. We use these differences to evaluate the effectiveness of fractions in stabilizing $\mathrm{C}$ against decomposition after burial. In short, roughly $1 \mathrm{mg} \mathrm{C}$ was sealed into an evacuated Pyrex tube and reduced to graphite (Xu et al., 2007). Sample preparation backgrounds have been subtracted, based on measurements of ${ }^{14} \mathrm{C}$-free coal. The radiocarbon signature of the graphite was measured with accelerator mass spectrometry (NEC 0.5MV 1.5SDH-2 AMS system) at the Keck-Carbon Cycle AMS facility at UC Irvine (CA, USA). Results have been corrected for isotopic fractionation according to the conventions of Stuiver and Polach (1977), with $\delta^{13} \mathrm{C}$ values measured on the prepared graphite using the AMS spectrometer. Radiocarbon concentrations are given as fractions of a modern oxalic acid standard and conventional radiocarbon age following the conventions of Stuiver and Polach (1977).

\subsection{Implementation and statistical analyses}

All statistical analysis was realized using SAS 9.3 (SAS Institute Inc., Cary, NC) and R 2.11.1 (R Development Core Team, 2010). Differences between the means of classes have been performed using multi-group ANOVA Bonferroni corrections and Tamhane's $\mathrm{T} 2$. We also performed linear regressions to test correlations between the abundance of the reactive soil phases and SOC in the bulk soil and for the isolated fractions. All statistical tests were evaluated using $p<0.1$ as the level of significance.

\section{Results}

\subsection{Total reserve in bases and degree of soil weathering along the hillslope}

The TRB for the loess parent material was $139 \mathrm{cmol}_{\mathrm{c}} \mathrm{kg}^{-1}$. For the different soil layers, TRB ranged between 101 and $118 \mathrm{cmol}_{\mathrm{c}} \mathrm{kg}^{-1}$, which represents a TRB loss of $15-27 \%$. These values are in the same range as reported for other Luvisol profiles in the region (Brahy and Delvaux, 2001). Losses in TRB are mostly related to decalcification (Ca losses compared to parent material: $80 \pm 2 \%$ ) (Table 2). The strongest losses of cations (lowest TRB in Table 2), and hence the most advanced weathering stage, are observed for the deposited soils at the foothill (relative difference of TRB at the depositional site compared to the loess parent material: $25-27 \%$ ), while the layers at the eroding hillslope have been facing the lowest losses of cations (highest TRB in Table 2), and hence the weakest degree of weathering (relative difference of TRB at the depositional site compared to the loess parent material 15-20\%). Nevertheless, these differences are small compared to differences between soil types in the same region (Brahy et al., 2001) and indicate a rather small effect of soil redistribution on TRB in comparison. At the stable plateau and the eroding hillslope, a significant difference $(p<0.1)$ with higher TRB at greater depth can be observed, but with weaker increases of TRB with soil depth than reported from similar soils (Brahy et al., 2001). In contrast, no effect of depth on TRB was observed in the depositional profile. 
Table 2. Total $\mathrm{Ca}, \mathrm{K}, \mathrm{Mg}$ and $\mathrm{Na}$ content and TRB values for the soil profiles at several depths and for the parent material.

\begin{tabular}{|c|c|c|c|c|c|c|c|c|c|c|c|}
\hline \multirow{2}{*}{$\begin{array}{l}\text { Parameter } \\
\text { Depth }\end{array}$} & \multirow{2}{*}{$\begin{array}{l}\text { Unit } \\
{[\mathrm{cm}]}\end{array}$} & \multicolumn{3}{|c|}{$\begin{array}{l}\text { Stable } \\
\text { plateau }\end{array}$} & \multicolumn{3}{|c|}{$\begin{array}{l}\text { Eroding } \\
\text { slope }\end{array}$} & \multicolumn{3}{|c|}{$\begin{array}{l}\text { Depositional } \\
\text { footslope }\end{array}$} & \multirow{2}{*}{$\begin{array}{c}\text { Parent materia } \\
\text { (loess) }\end{array}$} \\
\hline & & $0-15$ & $35-50$ & $55-70$ & $0-15$ & $35-50$ & $55-70$ & $0-15$ & $35-50$ & $55-70$ & \\
\hline $\mathrm{Ca}$ & & 14 & 13 & 13 & 15 & 12 & 14 & 15 & 13 & 13 & 70 \\
\hline $\mathrm{K}$ & & 46 & 46 & 48 & 47 & 50 & 46 & 42 & 41 & 43 & 32 \\
\hline $\mathrm{Mg}$ & {$\left[\mathrm{cmol}_{\mathrm{c}} \mathrm{kg}^{-1}\right]$} & 15 & 20 & 19 & 17 & 19 & 19 & 14 & 14 & 16 & 18 \\
\hline $\begin{array}{l}\text { TRB relative } \\
\text { to parent material }\end{array}$ & $(\%)$ & 77 & 81 & 81 & 80 & 83 & 85 & 75 & 73 & 74 & 100 \\
\hline
\end{tabular}
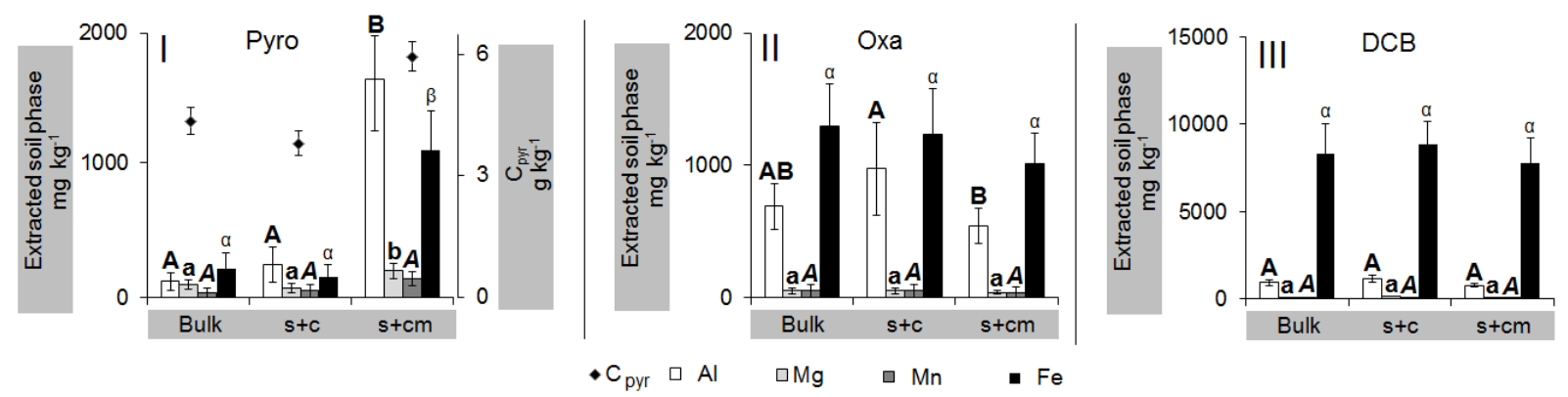

Figure 2. The distribution of pyrophosphate (I), oxalate (II) and dithionite (III) extractable Al, Mn and Fe between the bulk soil and its compartments non-aggregated silt + clay $(\mathrm{s}+\mathrm{c})$ and aggregated silt + clay $(\mathrm{s}+\mathrm{cm})$ for all depths and positions combined (bars). Dots represent the the $\mathrm{C}$ extracted by pyrophosphate for the bulk soil and the fractions (Panel I only). Different letters above bars indicate a significant difference $(p<0.1$, tested for extracted element in the different SOC fractions and treatments separately as indicated by differences in font types).

\subsection{Reactive soil phases}

Pyrophosphate extractable components are generally abundant in microaggregates, especially as $\mathrm{Fe}(\mathrm{p})$ $\left(1118 \pm 293 \mathrm{mg} \mathrm{kg}^{-1}\right.$ soil $)$ and $\mathrm{Al}(\mathrm{p})\left(1647 \pm 385 \mathrm{mg} \mathrm{kg}^{-1}\right.$ soil) (Fig. 2). The ratio of non-aggregated to aggregated pyrophosphate extracts in silt and clay is generally between $1: 3$ and $1: 7$ and shows a clear association of these components with soil microaggregates. In contrast, oxalate and DCB extractable phases do not show such a pattern between aggregated and non-aggregated soil samples. No significant differences in the amount of oxalate and DCB extractable components in aggregated vs. non-aggregated soil fractions were detected for $\mathrm{Fe}, \mathrm{Mg}$, and $\mathrm{Mn}$. $\mathrm{Al}(\mathrm{o})$ showed about $40 \%$ lower concentrations in non-aggregated silt and clay $(\mathrm{s}+\mathrm{c})$ compared to aggregated silt and clay $(\mathrm{s}+\mathrm{cm})$. Approximately the same amount of oxalate extractable $\mathrm{Al}, \mathrm{Fe}, \mathrm{Mg}$, and $\mathrm{Mn}$ is present in aggregated $\left(1690 \pm 378 \mathrm{mg} \mathrm{kg}^{-1}\right.$ soil) and non-aggregated $\left(2421 \pm 648 \mathrm{mg} \mathrm{kg}^{-1}\right.$ soil) soil samples, with 5 times more DCB extractable elements than oxalate in both soil compartments.

Despite the small contribution of $\mathrm{Mn}(\mathrm{p})$ $\left(40 \pm 36 \mathrm{mg} \mathrm{kg}^{-1}\right.$ soil) to the total pyrophosphate ex- tractable phase of the bulk soil compared to $\mathrm{Al}(\mathrm{p})$ $\left(122 \pm 64 \mathrm{mg} \mathrm{kg}^{-1}\right.$ soil) and $\mathrm{Fe}(\mathrm{p})\left(222 \pm 115 \mathrm{mg} \mathrm{kg}^{-1}\right.$ soil $)$ and $\operatorname{Mg}(\mathrm{p})\left(101 \pm 33 \mathrm{mg} \mathrm{kg}^{-1}\right.$ soil), it is the only phase with a significant correlation to SOC in the bulk soil across the whole slope transect (Fig. 3). Table 3 shows that the positive correlation of $\mathrm{Mn}(\mathrm{p})$ with SOC along the slope for the bulk soil is driven by the non-aggregated silt and clay fractions. In contrast to $\mathrm{Mn}(\mathrm{p})$, a correlation of $\mathrm{Fe}(\mathrm{p})$ and $\mathrm{Al}(\mathrm{p})$ with SOC could only be identified at the depositional site. Poor or negative correlations were found for all pyrophosphate extractable phases with SOC in the microaggregate silt and clay $(\mathrm{s}+\mathrm{cm})$ fraction. Depth patterns of $\mathrm{Al}(\mathrm{p}), \mathrm{Fe}(\mathrm{p})$ and $\operatorname{Mg}(\mathrm{p})$ are not consistent for eroding and stable profiles, but a significant decrease with depth can be recognized at the depositional site. $\mathrm{Mn}(\mathrm{p})$, on the other hand, decreases significantly $(p<0.1)$ with depth at all slope positions except for $\mathrm{s}+\mathrm{c}$ at the depositional site and for $\mathrm{s}+\mathrm{cm}$ at the eroding and depositional site. 
Table 3. Correlations (Pearson $r$ ) between pyrophosphate, oxalate and DCB extractable solid soil phases and SOC or soil depth $\left(^{*}=p<0.1\right.$ ).

\begin{tabular}{|c|c|c|c|c|c|c|c|c|c|c|c|c|c|c|}
\hline \multirow[t]{2}{*}{ SOC fraction } & \multirow[t]{2}{*}{ Position } & \multirow[t]{2}{*}{ Parameter } & \multicolumn{4}{|c|}{ Pyrophosphate extractable } & \multicolumn{4}{|c|}{ Oxalate extractable } & \multicolumn{4}{|c|}{ DCB extractable } \\
\hline & & & $\mathrm{Al}_{(\mathrm{p})}$ & $\mathrm{Fe}_{(\mathrm{p})}$ & $\mathrm{Mg}_{(\mathrm{p})}$ & $\mathrm{Mn}_{(\mathrm{p})}$ & $\mathrm{Al}_{(\mathrm{o})}$ & $\mathrm{Fe}_{(\mathrm{o})}$ & $\mathrm{Mg}_{(\mathrm{o})}$ & $\mathrm{Mn}_{(\mathrm{o})}$ & $\mathrm{Al}_{(\mathrm{d})}$ & $\mathrm{Fe}_{(\mathrm{d})}$ & $\mathrm{Mg}_{(\mathrm{d})}$ & $\mathrm{Mn}_{(\mathrm{d})}$ \\
\hline \multirow{9}{*}{ Bulk soil } & \multirow{3}{*}{ Non-eroding } & Pearson $r$ phase vs. depth & 0.34 & -0.45 & -0.27 & $-0.95^{*}$ & $0.84^{*}$ & 0.09 & $-0.73^{*}$ & 0.37 & $0.74^{*}$ & $0.84^{*}$ & 0.60 & $0.61^{*}$ \\
\hline & & Pearson $r$ phase vs. SOC & -0.37 & 0.4 & 0.06 & $0.99^{*}$ & $-0.87^{*}$ & 0.02 & $0.84^{*}$ & -0.09 & -0.57 & $-0.68^{*}$ & -0.33 & -0.36 \\
\hline & & Range $\mathrm{mg} \mathrm{kg}^{-1}$ & $70-223$ & $118-410$ & $62-119$ & $6-73$ & $647-1076$ & $1512-1928$ & $38-75$ & $255-379$ & $788-1280$ & $6401-12161$ & $81-132$ & $43-60$ \\
\hline & \multirow{3}{*}{ Eroding slope } & Pearson $r$ phase vs. depth & 0.17 & -0.12 & 0.1 & $-0.9^{*}$ & 0.09 & $-0.85^{*}$ & -0.41 & 0.83 & 0.18 & 0.57 & 0.53 & -0.53 \\
\hline & & Pearson $r$ phase vs. SOC & 0.04 & 0.34 & 0.13 & $0.99^{*}$ & -0.38 & $0.75^{*}$ & 0.41 & -0.95 & -0.35 & $-0.72^{*}$ & -0.54 & 0.55 \\
\hline & & Range $\mathrm{mg} \mathrm{kg}^{-1}$ & $53-298$ & $91-498$ & $58-207$ & $6-84$ & $554-865$ & $829-1531$ & $42-66$ & 191-282 & $783-1027$ & $6277-9593$ & $73-128$ & $44-79$ \\
\hline & \multirow{3}{*}{$\begin{array}{l}\text { Depositional } \\
\text { footslope }\end{array}$} & Pearson $r$ phase vs. depth & -0.23 & $-0.67^{*}$ & -0.68 & $-0.99^{*}$ & $0.83^{*}$ & 0.05 & -0.43 & $0.99^{*}$ & 0.5 & $0.64^{*}$ & 0.29 & 0.25 \\
\hline & & Pearson $r$ phase vs. SOC & 0.23 & $0.67^{*}$ & 0.69 & $0.99^{*}$ & $-0.83^{*}$ & -0.05 & 0.43 & $-0.99^{*}$ & -0.49 & $-0.64^{*}$ & -0.29 & -0.25 \\
\hline & & Range $\mathrm{mg} \mathrm{kg}^{-1}$ & $58-180$ & $106-320$ & $69-133$ & $18-112$ & $432-636$ & $930-1157$ & $40-65$ & $181-265$ & $569-1234$ & $5319-10324$ & $67-146$ & $41-60$ \\
\hline \multirow{9}{*}{$\begin{array}{l}\text { Non-aggregated } \\
\mathrm{s}+\mathrm{c}\end{array}$} & \multirow{3}{*}{ Non-eroding } & Pearson $r$ phase vs. depth & $0.61^{*}$ & 0.05 & 0.24 & $-0.88^{*}$ & -0.17 & -0.33 & 0.19 & -0.42 & 0.8 & $0.97^{*}$ & 0.12 & 0.56 \\
\hline & & Pearson $r$ phase vs. SOC & -0.47 & 0.2 & -0.02 & $0.95^{*}$ & -0.08 & 0.57 & 0.18 & 0.46 & $-0.92^{*}$ & $-0.99^{*}$ & 0.17 & -0.39 \\
\hline & & Range $\mathrm{mg} \mathrm{kg}^{-1}$ & $105-403$ & $67-252$ & $42-93$ & $10-107$ & $792-1842$ & $1557-1858$ & $38-75$ & $152-301$ & $1003-1626$ & $7188-10760$ & 100-137 & $53-57$ \\
\hline & \multirow{3}{*}{ Eroding slope } & Pearson $r$ phase vs. depth & 0.44 & 0.18 & 0.29 & $-0.74^{*}$ & 0.16 & $-0.92^{*}$ & 0.29 & $0.64^{*}$ & 0.21 & $0.59^{*}$ & $0.78^{*}$ & 0.54 \\
\hline & & Pearson $r$ phase vs. SOC & -0.27 & -0.06 & -0.12 & $0.72^{*}$ & -0.49 & $0.81^{*}$ & -0.36 & $-0.77^{*}$ & -0.32 & $-0.81^{*}$ & $-0.82^{*}$ & -0.46 \\
\hline & & Range $\mathrm{mg} \mathrm{kg}^{-1}$ & $87-568$ & $46-362$ & $33-152$ & $4-153$ & $746-1035$ & $686-1360$ & $42-63$ & $113-168$ & $1016-1294$ & $8288-10783$ & $115-172$ & $50-56$ \\
\hline & \multirow{3}{*}{$\begin{array}{l}\text { Depositional } \\
\text { footslope }\end{array}$} & Pearson $r$ phase vs. depth & $-0.76^{*}$ & -0.48 & -0.5 & -0.5 & 0.54 & 0.55 & 0.57 & 0.29 & $0.71^{*}$ & $0.76^{*}$ & 0.07 & $0.85^{*}$ \\
\hline & & Pearson $r$ phase vs. SOC & $0.76^{*}$ & 0.48 & 0.5 & 0.5 & -0.46 & -0.51 & $-0.63^{*}$ & -0.2 & $-0.71^{*}$ & $-0.76^{*}$ & -0.07 & $-0.85^{*}$ \\
\hline & & Range $\mathrm{mg} \mathrm{kg}^{-1}$ & $107-425$ & $73-271$ & $31-125$ & $13-168$ & $513-871$ & $802-1085$ & $44-62$ & $68-175$ & $855-1087$ & $6612-8795$ & $117-167$ & $45-69$ \\
\hline \multirow{9}{*}{$\begin{array}{l}\text { Aggregated } \\
\mathrm{s}+\mathrm{cm}\end{array}$} & \multirow{3}{*}{ Non-eroding } & Pearson $r$ phase vs. depth & $0.80^{*}$ & 0.58 & 0.5 & $-0.69^{*}$ & $0.75^{*}$ & $0.62 *$ & 0.42 & 0.52 & 0.33 & 0.54 & 0.21 & -0.4 \\
\hline & & Pearson $r$ phase vs. SOC & $-0.96^{*}$ & $-0.76^{*}$ & $-0.64^{*}$ & $0.81^{*}$ & $-0.98^{*}$ & $-0.77^{*}$ & 0.07 & $-0.82^{*}$ & $-0.82^{*}$ & $-0.94 *$ & -0.54 & -0.21 \\
\hline & & Range $\mathrm{mg} \mathrm{kg}^{-1}$ & $1290-1947$ & $934-1189$ & $165-219$ & $62-169$ & $460-760$ & $1113-1476$ & $36-44$ & $85-166$ & $647-1004$ & $5797-9048$ & $73-103$ & $32-45$ \\
\hline & \multirow{3}{*}{ Eroding } & Pearson $r$ phase vs. depth & $0.68^{*}$ & 0.39 & 0.32 & -0.31 & $0.72^{*}$ & -0.41 & 0.52 & $0.93^{*}$ & 0.49 & 0.46 & $0.8^{*}$ & $0.65^{*}$ \\
\hline & & Pearson $r$ phase vs. SOC & 0.57 & $0.71^{*}$ & 0.58 & 0.38 & $-0.81^{*}$ & 0.39 & -0.55 & $-0.98^{*}$ & -0.61 & $-0.62^{*}$ & $-0.8^{*}$ & $-0.72^{*}$ \\
\hline & & Range $\mathrm{mg} \mathrm{kg}^{-1}$ & 1117-1954 & $681-1599$ & $142-291$ & $89-216$ & $463-688$ & $812-1050$ & $35-56$ & $69-124$ & 753-1064 & $7027-10764$ & $83-136$ & $34-40$ \\
\hline & \multirow{3}{*}{$\begin{array}{l}\text { Depositional } \\
\text { footslope }\end{array}$} & Pearson $r$ phase vs. depth & 0.2 & 0.37 & 0.34 & 0.43 & 0.27 & -0.38 & 0.22 & 0.52 & 0.2 & 0.52 & 0.61 & -0.32 \\
\hline & & Pearson $r$ phase vs. SOC & -0.27 & -0.25 & -0.09 & 0 & -0.22 & 0.4 & 0.16 & -0.54 & -0.24 & -0.49 & -0.21 & 0.37 \\
\hline & & Range $\mathrm{mg} \mathrm{kg}^{-1}$ & $1137-2685$ & $849-2021$ & $132-356$ & $58-221$ & $286-529$ & $640-945$ & $32-50$ & $39-66$ & $557-789$ & $5017-7972$ & $78-114$ & $29-33$ \\
\hline
\end{tabular}

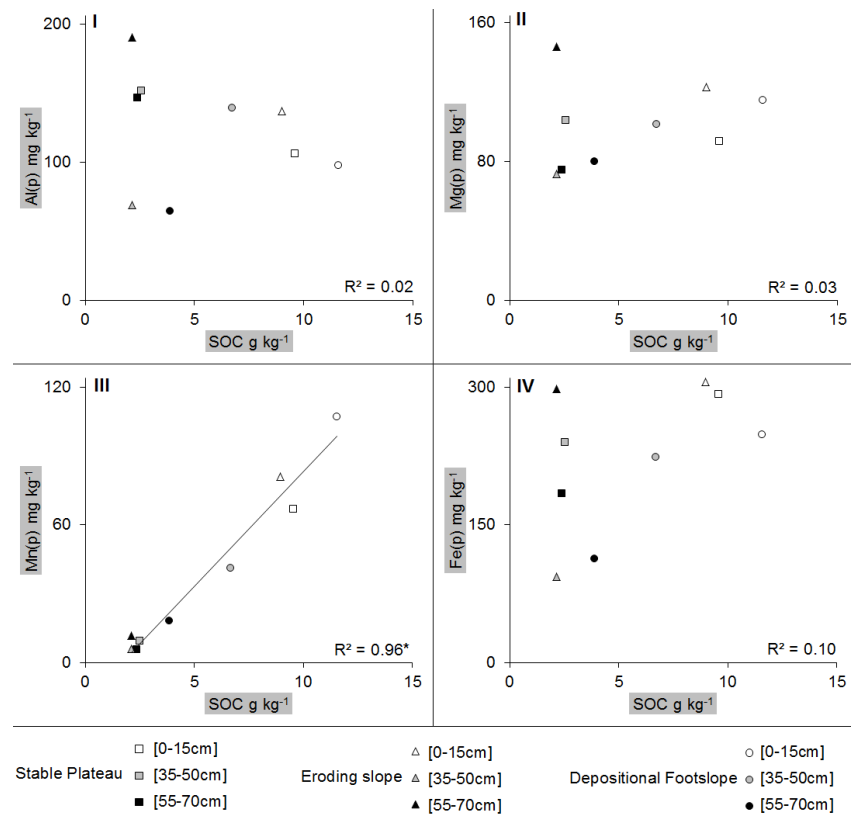

Figure 3. Mean SOC $\left(\mathrm{g} \mathrm{kg} \mathrm{soil}^{-1}\right)$ and pyrophosphate extractable $\mathrm{Al}$ (I), Mg (II), Mn (III), and Fe (IV).

No strong correlation of oxalate extractable phases in the bulk soil, $\mathrm{s}+\mathrm{c}$ or $\mathrm{s}+\mathrm{cm}$ with SOC could be identified. Oxalate and DCB and extractable elements are generally not significant or negatively correlated to SOC, except for a significantly positive correlation of $\mathrm{Fe}(\mathrm{o})$ to $\mathrm{SOC}$ in the bulk soil and non-aggregated silt and clay fraction.

\subsection{Clay-sized fraction mineralogy}

The abundance of secondary and primary minerals in the clay fraction differs largely along the transect and for different depths (Fig. 4), while the concentration of quartz remains fairly constant across the different transect profiles and soil depths $(15 \pm 1.6 \%$, data not shown). Generally, the eroding slope profile has the highest number of investigated primary minerals (26-45\%), while the lowest values are measured at the stable plateau (31-36\%) and the deepest layer of the depositional site $(26 \pm 0.6 \%)$. The opposite trend can be observed for the abundance of pedogenic secondary minerals with the highest contents measured at the stable plateau (40$62 \%)$ and the depositional site (38-52\%) while the erosional profile shows the lowest values (35-42\%). A closer analysis of the secondary mineral fraction of all investigated soils shows the presence of both expandable (vermiculite, smectite) and non-expandable 2:1 layered clay minerals (illite; chlorite). Also larger amounts of $1: 1$ layered clays such as kaolinite were found, partly inherited from the parent material and as to be expected in Luvisols of this region (Van Ranst et al., 1982; Fig. 4). Within the clay fraction, the expandable $2: 1$ layered mineral ranges between $6-26 \%$ relative abundance with highest values at the depositional topsoil $(26.1 \pm 0.5 \%)$ and lowest values at the eroding slope topsoil $(5.9 \pm 0.4 \%)$. The abundance of illite is highest at the erosional subsoils $(32 \pm 0.9 \%)$, with no clear depth- or sloperelated pattern for the remaining samples (10-24\%), while the highest relative abundance of chlorite has been measured at the depositional deeper $(55-70 \mathrm{~cm})$ subsoil $(49 \pm 0.7 \%)$. 


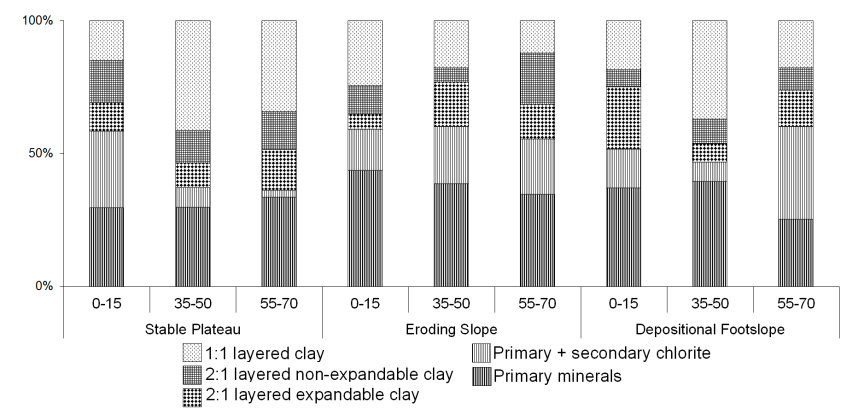

Figure 4. Composition of the mineral phase and quantification of primary vs. secondary minerals for the different slope positions and soil depths of the clay sized fraction (no distinction between primary and secondary chlorite).

Kaolinite contents are generally increasing with depth at the stable plateau (22-62\%) and decreasing with depth at the eroding profile (46-22\%), while no pattern was observed for the depositional profile (35-64\%).

\subsection{AS abundance}

The contribution of AS $\mathrm{mg} \mathrm{g}^{-1}$ SOC (Fig. 5) at the depositional site is several times higher than at other positions, especially for glucosamine. Generally, AS concentrations per unit $\mathrm{C}$ decrease with the size of the fraction and are especially low in the non-aggregated silt and clay fraction. In addition, the non-aggregated silt and clay fraction shows generally the highest differences between topsoil and subsoil abundance of AS per unit $\mathrm{C}$ at all slope positions; this is especially pronounced at the stable plateau and eroding slope position. Moreover, the bulk soil AS values are similar for the topsoil along the slope (GalN-C: $22.5 \pm 1.9 \mathrm{mg} \mathrm{g}^{-1}$ SOC; GluN-C: $34.7 \pm 22.2 \mathrm{mg} \mathrm{g}^{-1}$ SOC) with highest values at the depositional site. In contrast, subsoils of the stable plateau (GalN-C: $7.2 \pm 0.6 \mathrm{mg} \mathrm{g}^{-1}$ SOC; GluN-C: $16.3 \pm 4.6 \mathrm{mg} \mathrm{g}^{-1}$ SOC) and the eroding slope (GalN-C: $6.3 \pm 1.0 \mathrm{mg} \mathrm{g}^{-1}$ SOC; GluN-C: $15.7 \pm 3.5 \mathrm{mg} \mathrm{g}^{-1}$ SOC) profile show significantly $(p>0.1)$ lower values compared to subsoils at the depositional site (GalN-C: $25.1 \pm 6.1 \mathrm{mg} \mathrm{g}^{-1}$ SOC; GluN-C: $54.2 \pm 6.9 \mathrm{mg} \mathrm{g}^{-1}$ SOC). All fractions contain a large portion of AS per unit $\mathrm{C}$ in the topsoil (GalN-C: $19.1 \pm 3.5 \mathrm{mg} \mathrm{g}^{-1} \mathrm{C}$; GluN-C: $42.0 \pm 9.7 \mathrm{mg} \mathrm{g}^{-1} \mathrm{C}$ ), while in subsoils the contribution of AS to total $\mathrm{C}$ is higher in the macroaggregates (GalN-C: $16.3 \pm 2.5 \mathrm{mg} \mathrm{g}^{-1} \mathrm{C}$; GluN$\mathrm{C}: 36.5 \pm 7.3 \mathrm{mg} \mathrm{g}^{-1} \mathrm{C}$ ) than in the microaggregate (GalNC: $\quad 12.7 \pm 6.0 \mathrm{mg} \mathrm{g}^{-1} \mathrm{C}$; GluN-C: $31.1 \pm 13.0 \mathrm{mg} \mathrm{g}^{-1} \mathrm{C}$ ) and the non-aggregated silt and clay fraction (GalN-C: $6.5 \pm 5.7 \mathrm{mg} \mathrm{g}^{-1} \mathrm{C}$; GluN-C: $12.2 \pm 12.2 \mathrm{mg} \mathrm{g}^{-1} \mathrm{C}$ ). Interestingly, at the depositional site, the amount of AS per unit $\mathrm{C}$ in the microaggregate and non-aggregated silt and clay fraction decreases with depth compared to the macroaggregate fraction, where no such trend could be observed (Fig. 5).
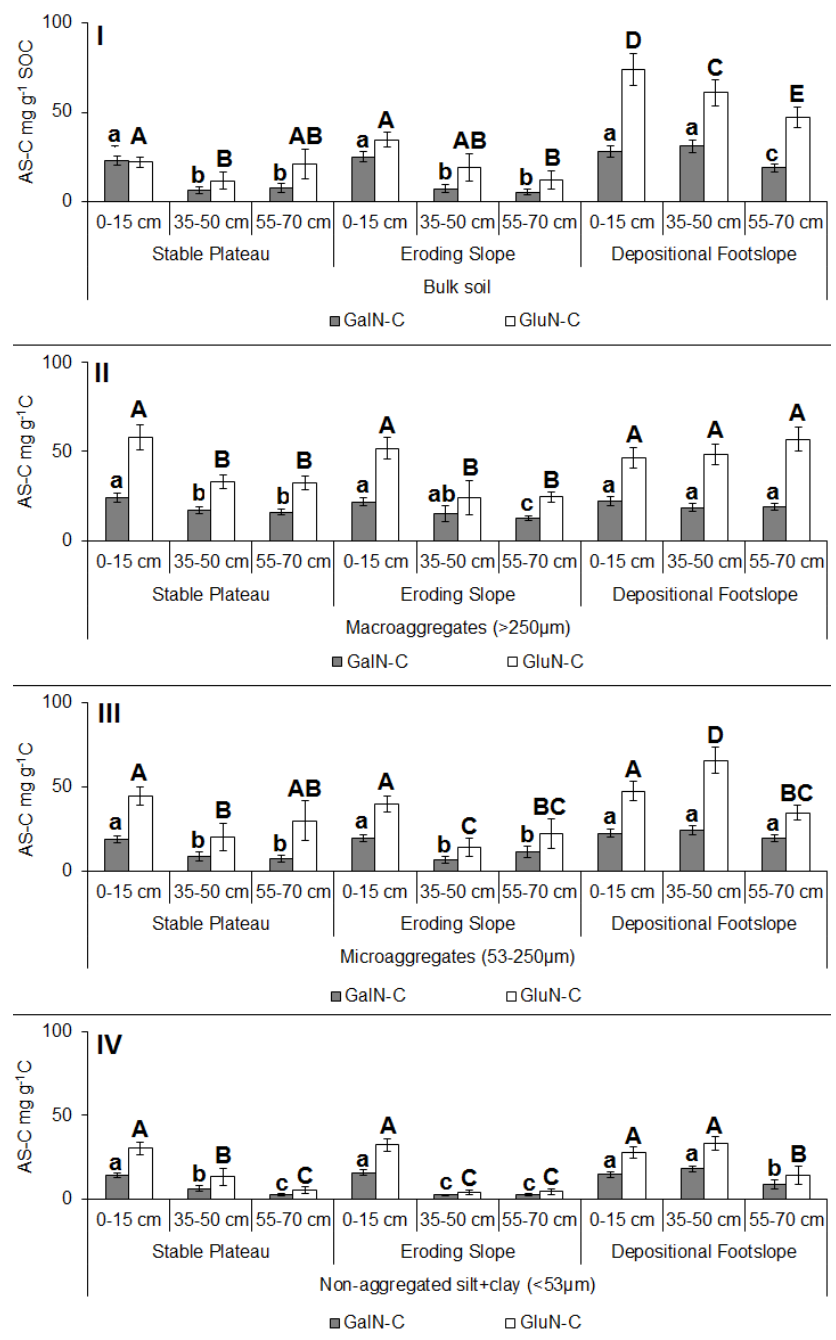

Figure 5. AS per unit SOC in the bulk soil (I) and the fractions (IIIV) along the slope and for different depths. Different letters above bars indicate a significant difference $(p<0.1$, for the two different AS and the bulk soil and three fractions separately as indicated by differences in font types).

The abundance of the two investigated AS is closely correlated to SOC in the bulk soil and across all fractions (Table 4), whereas the correlation of GalN to SOC is higher $\left(r=0.97^{*}\right)$ than the correlation of GluN to SOC $(r=0.71 *)$. The smallest changes in the abundance of AS and SOC g soil ${ }^{-1}$ (Fig. 5) are observed between topsoil and subsoil in the macroaggregate fractions (Ratio topsoil vs. subsoil: 1.7-3.6), while changes in the microaggregate fractions (Ratio topsoil vs. subsoil: 3.1-11.5) and especially in the non-aggregated silt and clay fractions are much higher (Ratio top- vs. subsoil: 4.9-32.8). Generally, the highest abundance of AS was found in topsoils, and the lowest in deeper subsoil layers. But this trend is much weaker in the depositional profile than in the non-eroding plateau and eroding slope profile. 
Table 4. Correlations (Pearson $r$ ) between SOC and the extracted AS galactosamine (GalN) and glucosamine (GlcN) from different fractions $(*=p<0.1)$.

\begin{tabular}{|c|c|c|c|c|}
\hline & Bulk soil & Macroaggregate & Microaggregate & Non-aggregated $\mathrm{s}+\mathrm{c}$ \\
\hline Pearson $r$ GalN-C & $0.97^{*}$ & $0.87^{*}$ & $0.94^{*}$ & $0.92^{*}$ \\
\hline Pearson $r$ GlcN-C & $0.71^{*}$ & $0.76^{*}$ & $0.96^{*}$ & $0.87^{*}$ \\
\hline N Observations GalN-C & 31 & 16 & 19 & 18 \\
\hline N Observations GlcN-C & 31 & 14 & 16 & 20 \\
\hline 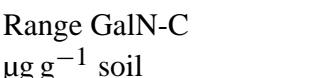 & $12-325$ & $33-360$ & $4-248$ & $2-206$ \\
\hline $\begin{array}{l}\text { Range GlcN-C } \\
\mu \mathrm{gg}^{-1} \text { soil }\end{array}$ & $26-860$ & $60-887$ & $23-546$ & $4-403$ \\
\hline $\begin{array}{l}\text { Mean GalN-C } \\
{\mu g^{-1}}^{-1} \text { soil }\end{array}$ & $296 \pm 280$ & $172 \pm 93$ & $100 \pm 82$ & $69 \pm 65$ \\
\hline $\begin{array}{l}\text { Mean GlcN-C } \\
\mu \mathrm{g} \mathrm{g}^{-1} \text { soil }\end{array}$ & $555 \pm 679$ & $396 \pm 224$ & $228 \pm 183$ & $138 \pm 130$ \\
\hline
\end{tabular}

Table 5. Conventional radiocarbon ages for investigated fractions for different depths at the depositional site.

\begin{tabular}{lrr}
\hline Fraction & $\begin{array}{r}\text { Depth } \\
(\mathrm{cm})\end{array}$ & $\begin{array}{r}{ }^{14} \mathrm{C} \text { age } \\
(\text { years BP })\end{array}$ \\
\hline Macroaggregates & $0-15$ & $975 \pm 15$ \\
$(>250 \mu \mathrm{m})$ & $35-50$ & $2275 \pm 20$ \\
& $55-70$ & $3090 \pm 20$ \\
Microaggregates & $0-15$ & $680 \pm 15$ \\
$(<250-53 \mu \mathrm{m})$ & $35-50$ & $1680 \pm 15$ \\
& $55-70$ & $2670 \pm 20$ \\
Non-aggregated silt & $0-15$ & $635 \pm 15$ \\
and clay $(<53 \mu \mathrm{m})$ & $35-50$ & $1835 \pm 15$ \\
& $55-70$ & $2200 \pm 15$ \\
\hline
\end{tabular}

\subsection{Radiocarbon ages for fractions at the depositional site}

The measured ${ }^{14} \mathrm{C}$ ages (years BP) for the investigated fractions at the depositional site differ widely for different soil depths (Table 5). Generally, the ${ }^{14} \mathrm{C}$ ages increase with depth and range between $635 \pm 15$ and $3655 \pm 15$ years. Consistently, the macroaggregate fraction has the oldest ${ }^{14} \mathrm{C}$ age at all depths of all fractions ( $975 \pm 15-3090 \pm 20$ years), representing distinctively older $\mathrm{C}$ than associated with the respective microaggregate ( $680 \pm 15-2670 \pm 20$ years) or nonaggregated silt and clay fraction (635 $\pm 15-2200 \pm 15$ years). Furthermore, the data show a shift in the relative age of microaggregate vs. non-aggregated C. In the topsoil and shallow subsoil the measured ${ }^{14} \mathrm{C}$ ages for these fractions are rather similar (difference of approx. 50-150 yr). In the deepest subsoil a clear distinction can be observed, with microaggregate associated $\mathrm{C}$ being 500 years older than $\mathrm{C}$ associated with non-aggregated silt and clay. Hence, ${ }^{14} \mathrm{C}$ ages for the non-aggregated silt and clay fraction in subsoils indicate a relatively young age of this fraction compared to the aggregated fractions.

\section{Discussion}

\subsection{Organo-mineral interactions along the toposequence}

The reactive mineral phases, predominantly manganese, that are related to the abundance of SOC seem to be largely extracted with pyrophosphate (Fig. 3, Table 3). Hence, we suggest that manganese significantly influences the dynamics of SOC in the investigated soil profiles by promoting the formation of organo-mineral complexes and by the redistribution of these complexes along the toposequence. The measured $\mathrm{C}$ concentrations in the pyrophosphate extract (Panel I, Fig. 2) represented about $81 \%$ of the total bulk $\mathrm{C}$ in these soils. This points to a minor importance of well-crystallized minerals to stabilize C, as extracted with DCB, and confirms earlier findings. Kodama and Schnitzer (1980) could show that the presence of organic ligands in the soil solution can prevent the formation of crystalline $\mathrm{Al}$ and $\mathrm{Fe}$ oxy-hydroxides, e.g., due to strong complexation gradients of fulvic acids with metals which prevent their complete hydroxylation. However, the absence of correlations between SOC and poorly crystalline minerals extracted with oxalate is contradictory to former studies (Kodama and Schnitzer, 1980; Kaiser and Zech, 1996; Mikutta et al., 2009). Oxalate extractable soil phases are generally assumed to be the most reactive group in many types of soils and presumably strong candidates for stabilizing SOC with minerals by adsorption on mineral surfaces (Huang et al., 1977; Kaiser and Guggenberger, 2003; Kleber et al., 2005; Eusterhues et al., 2005). We interpret our result in terms of (i) the applied extraction scheme, (ii) the specific soil conditions in which interactions between the reac- 
tive mineral phase and SOC take place, and (iii) the varying mobility of the extracted phases in those soils.

First, in contrast to many other studies, our extraction is sequential, with pyrophosphate, oxalate, and DCB applied in this order on the same sample. Other studies that do not use pyrophosphate extract with oxalate a potentially large part of organo-mineral associations. These associations are in our design already partly extracted with pyrophosphate. Second, even though concentrations of pyrophosphate extracted iron and aluminum were high in microaggregates, no strong positive correlations with $\mathrm{C}$ were found for these elements (Table 3, Fig. 2). The fact that pyrophosphate extractable elements are generally abundant in aggregates raises questions about the importance of the isolated elements for supporting the physical protection of $\mathrm{C}$ against decomposition. One explanation could be that pyrophosphate extractable $\mathrm{Fe}$ and $\mathrm{Al}$ are important for aggregate stability as ligands between clay minerals, even without involving SOC, but not for SOC retention itself. $\mathrm{Fe}(\mathrm{p})$ and $\mathrm{Al}(\mathrm{p})$ could act as proxies for the formation of aggregates through the formation of organometallic complexes, but also through the formation of $\mathrm{Fe}, \mathrm{Al}$ oxy-hydroxides (Kaiser and Zech, 1996). Pyrophosphate in that case might simply act as a strong reagent to disaggregate soil (Muneer and Oades, 1989) and therefore the abundance of pyrophosphate extractable elements in aggregates does not point at an identifiable group of organo-mineral associations (Kaiser and Zech, 1996). Third, the pH-values in our soils are near neutral (Table 1), which implies a $\mathrm{pH}$ buffer zone where $\mathrm{Mn}$ is highly mobile as $\mathrm{Mn}^{2+}$, potentially forming organo-mineral complexes, while the mobility of $\mathrm{Fe}$ and $\mathrm{Al}$ is strongly limited at $\mathrm{pH}>6$ (Lindsay, 1979). However, the data indicate a potential impact of oxalate extractable Fe oxides to stabilize SOC where physical protection of SOC by aggregation is weak, namely at the eroding site (Table 3). There, the aggregation potential is small (Doetterl et al., 2012) due to the continuous removal of aggregate-rich topsoil layers.

\subsection{Importance of clay-sized mineral distribution}

The presented data for the abundance of different clay-sized minerals (Fig. 4) clearly indicate a large variety of clay minerals along the slope transect. In combination with the high TRB values at the eroding site, the large abundance of primary minerals and illite (=non-expandable 2:1 layered clay) and the relatively low content of pedogenic clay minerals (1:1 and 2:1 layered clay minerals) indicate a lower level of weathering at the eroding compared to the plateau and depositional site. These data are in accordance with the general assumption that kaolinite is one of the end products in the weathering sequence in soils and that the eroding profile is less weathered than the stable and depositional profile (see Sect. 3.1). The deepest layer of the eroding profile is the least weathered part of soil along the sequence. Kaolinite there is mostly derived from the parent material, hence lowest in comparison to other samples undergoing more advanced weathering.

The applied quantitative approach allows us to document a relative depletion of expandable $2: 1$ clay minerals (smectite and vermiculite) in the topsoil of the eroding site $(3.2 \pm 0.4 \%)$ and their enrichment in the topsoil of the depositional site $(15.4 \pm 1.7 \%)$. This suggests the preferential mobilization of smectite and vermiculite at the eroding site and their deposition at the foothill as soil gets mobilized and eroded mostly as aggregates (Wang et al., 2010). Aggregates dominated by expandable clay minerals have been identified to be less stable due to shrinking and swelling than kaolinite or illite-rich aggregates (Fan et al., 2008) or aggregates rich in amorphous and crystalline $\mathrm{Al}$ and Fe oxide (Goldberg, 1989). The lower stability of smectite or vermiculitedominated aggregates then leads to a preferential breakdown and mobilization of these aggregates, resulting in smaller particles more susceptible to erosion, leading to transport to and burial at depositional sites. Our data (Fig. 4 and Doetterl et al., 2012) are consistent with the observation of the preferential export of small particle sizes out of the catchment, which are often dominated by smectite colloids (Gibbs, 1967). At the depositional site, weathering continues and alters clay minerals which are involved in the formation of aggregates and SOC stabilization, for example by transforming expandable clay into non-expandable forms such as chloride (Fig. 4; depositional footslope $55-70 \mathrm{~cm}$ ). The two mechanisms together (weathering and transportation) can hence explain the low amount of aggregates at eroding sites, and the loss of aggregates with depth at the depositional site (Table 1) as weathering continues. However, we cannot elaborate on whether the breakdown of aggregates at the depositional site is induced first by decomposition of $\mathrm{C}$ or mineral weathering. Nevertheless, no strong and significant correlations between specific clay minerals and $\mathrm{C}$ content in different fractions or the clay content and SOC concentration could be identified along the slope (data not shown). Even though a direct quantification of the impact of clay minerals on stabilizing SOC is not possible with our analysis, the data indicate that in these soils with rather low bulk SOC concentrations of $1.2-0.2 \%$, clay surfaces are likely not the limiting factor for $\mathrm{C}$ stabilization, even if the amount of highly reactive clay minerals such as vermiculite or smectite is small. This is consistent with observations of Duemig et al. (2012), where higher SOC loadings of clay minerals were observed in consequence of a shortage of reactive surface area in clay-depleted soils compared to more clay-rich soils.

\subsection{Radiocarbon ages in relation to microbial residues, respiration, and particulate organic matter}

The fact that the AS content per unit $\mathrm{C}$ in the macroaggregate and, to a weaker extent, in the microaggregate and nonaggregated silt and clay fractions at the depositional site does not decrease significantly after burial, in comparison to very 


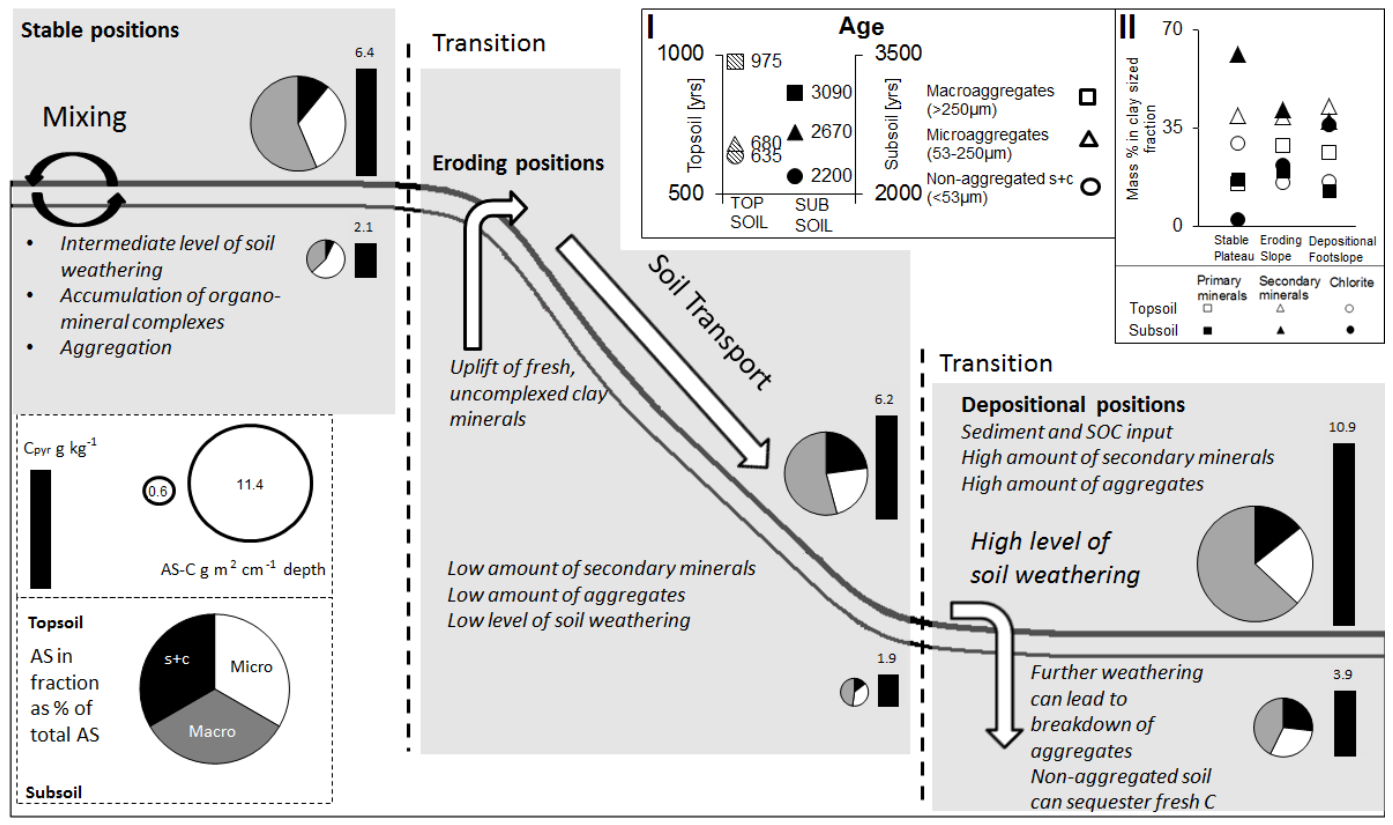

Figure 6. Conceptual figure showing the mineralogical changes along the slope in relation to the abundance of AS in non-aggregated silt and clay $(s+c)$, microaggregates, and macroaggregates. Statement on the level of soil weathering along the transect refers to both topsoil and subsoil. Pie charts show the relative contribution of AS in each fraction to total AS by multiplying AS g $\mathrm{C}^{-1}$ in a fraction with $\mathrm{C}$ stock estimates of the respective fraction given in Table 1. The size of the pie chart indicates the absolute AS content of these fractions combined in $\mathrm{g} \mathrm{m}^{-2}$ and per $\mathrm{cm}$ depth of a profile. The amount of $\mathrm{C}$ extracted with pyrophosphate in the bulk soil is given as a column next to each AS pie chart. Panels at the top right show the distribution of primary and secondary minerals along the slope in different depths (I) (see also Table 4) and the relative ${ }^{14} \mathrm{C}$ derived ages of these fractions in topsoil and subsoil for the depositional site (II), indicating differences between the fractions (see also Table 5).

low subsoil AS concentrations at the eroding site (Fig. 5), leads to the conclusion that burial of soil can lead to the storage of an otherwise relatively easily decomposable part of SOC in soils for decades and centuries. At the same time C in macroaggregates has shown the oldest ${ }^{14} \mathrm{C}$ ages of all isolated fractions (Table 5).

X. Wang et al. (2014) report, for a cropland slope from the same region with similar topographic setting, a reaggregation of deposited and buried $\mathrm{C}$ within macroaggregates. Our data showing old ${ }^{14} \mathrm{C}$ ages of macroaggregate associated $\mathrm{C}$ are supportive of this, indicating indeed a preferential accumulation of old carbon in macroaggregates at the depositional site (Table 5). The measured old ${ }^{14} \mathrm{C}$ ages and the high potential respiration rates measured for these soils rich in macroaggregates (i.e., Doetterl et al., 2012) indicate furthermore the presence of $\mathrm{C}$ sources with differing availability to decomposers within the macroaggregate fraction. On one hand, these aggregates represent a proper habitat for microorganisms to thrive on C (Denef et al., 2001). Respiration data (presented in our former work; Doetterl et al., 2012) clearly show that soils in this sequence with large amounts of macroaggregate $\mathrm{C}$ also respire at a higher rate than soils low on macroaggregate $\mathrm{C}$. On the other hand, the presence of high amounts of microbial residues (Fig. 5) can enhance the formation of stable aggregates (Bossuyt et al.,
2001; Cotrufo et al., 2012). Hence, macroaggregates represent hotspots of microbial life and activity (Kolb et al., 2009) with at the same time old ${ }^{14} \mathrm{C}$ ages, indicating higher stability. A conversion of SOC from non-microbial to microbial carbon within stable aggregates would then not alter the ${ }^{14} \mathrm{C}$ signature of the fraction, but the potential stability of this fraction would still change. This is supported by recent studies that highlight that the genetic variety of microbial communities is maintained in buried surface soils, and that large amounts of microbial biomass can be found in deeper layers of burial sites, driven by the abundance of organic matter as a nutrient source (Helgason et al., 2014). Hence, we argue that ${ }^{14} \mathrm{C}$ ages and high AS contents in macroaggregates indicate that microorganisms either feed on old carbon to build up microbial biomass, if conditions are suitable, or these environments contain considerable amounts of old $\mathrm{C}$ and are proper habitats for microorganisms where their residues are preserved.

\subsection{Soil redistribution and the depth-related changes of carbon at the depositional sites}

Our results show the ongoing rejuvenation of the soil at the eroding hillslope by removal of soil material and exposure of less weathered material to the surface. The lower loss of 
cations compared to the parent material (Table 2) indicates that the continuous removal of soil at the hillslope is acting at a faster rate than the natural soil weathering and this keeps the eroding profile TRB higher, and hence less weathered, than at the stable plateau site. This is consistent with the absence of a depth-related trend in the TRB at the depositional site (Table 2) as this material is buried former topsoil, similar in TRB. Changes in C stocks with depth at the depositional sites can shed light on the underlying mechanistic relationships as the buried topsoil should have similar $\mathrm{C}$ content and composition to the present topsoil if no changes in respect of the composition of $\mathrm{C}$ fractions have occurred, given the low $\mathrm{C}$ contents in subsoils of soils not affected by burial processes (Table 1). Hence, decreasing amounts of only certain fractions must be related to the decomposition of $\mathrm{C}$ within these fractions. Furthermore, comparing this decrease to $\mathrm{C}$ contents associated with other fractions allows assessment of information on the effectiveness of protection through a specific set of stabilization mechanisms after burial. A recently published study on SOC stabilization along a 500 year chronosequence from wetland to cropland in China illustrates the importance of understanding the interaction of stabilization mechanisms for SOC by pointing out that "beyond providing a physical barrier between microbes and carbon substrates, soil aggregation could contribute to SOC stabilization by bringing organic matter and soil particles together and promoting organo-mineral interaction" (Cui et al., 2014).

Contradicting the findings of X. Wang et al. (2014), our data indicate the strengthening effect of physical protection/aggregation on the stabilization of $\mathrm{C}$ against decomposition. While the relative contribution of $\mathrm{C}$ associated with the non-aggregated silt and clay fraction is increasing with depth (Table 1), its age compared to $\mathrm{C}$ associated with aggregates is becoming younger (Table 5). We conclude from this that nonaggregated $\mathrm{C}$ is not as stable against decomposition as is often assumed (Yu et al., 2011). Within aggregates, on the other hand, mineral surfaces are "locked away" from new $\mathrm{C}$ input similarly to how aggregated $\mathrm{C}$ is not as easily accessible for decomposers as non-aggregated $\mathrm{C}$ and can hence result in a slower turnover of this C. Instead, mineral surfaces of the non-aggregated silt and clay $\mathrm{C}$ can act very efficiently in stabilizing younger $\mathrm{C}$ (Eusterhues et al., 2005, 2008; Duemig et al., 2011, 2012), resulting in younger radiocarbon ages and at the same time similar $\mathrm{C}$ loading as for microaggregates (Table 5). However, the amount of macroaggregates and microaggregates is steadily decreasing with depth, indicating (i) the ongoing weathering of soils and hence alterations of minerals (Fig. 6) that build up the aggregates and (ii) that the slow but steady decomposition of $\mathrm{C}$ leads to a deterioration of aggregates and, hence, this mechanism of protecting $\mathrm{C}$ through physical isolation.

\section{Conclusions}

Our findings (Fig. 6) highlight (1) the control of the distribution of functional SOC fractions over soil redistribution; (2) that the abundance and weathering of clay minerals and pedogenic oxyhydroxides are partly responsible for the effectiveness of the geochemical and physical stabilization mechanism of SOC along the slope and with soil depth; (3) that mineral alteration and the breakdown of aggregates limit the protection of $\mathrm{C}$ by minerals and within aggregates temporally; (4) that pyrophosphate extractable iron and aluminum are important for aggregate stability but not for SOC retention in near neutral $\mathrm{pH}$ soils; (5) that the combined effect of geochemical and physical protection of $\mathrm{C}$ after burial is prevalent at the depositional sites but changes through time; and (6) that microorganisms feed on old carbon to build up microbial biomass within aggregates, or aggregates are environments containing considerable amounts of old $\mathrm{C}$ but where microorganisms thrive and their residues are preserved. The question remains, however: what is the importance of these findings for our understanding of $\mathrm{C}$ sequestration and potential sink and source functions in dynamic landscapes?

In conclusion, a considerable amount of $\mathrm{C}$ has been stabilized with the mineral phase. These minerals play a crucial role in supporting the dynamic replacement (Harden et al., 1999) of eroded $C$ with new $C$ input, while at the same time burying the eroded $\mathrm{C}$ at depositional sites can provide a potential sink for atmospheric C. However, this potential sink function is largely temporally and spatially limited. Due to the continued weathering and hence weakening of different protection mechanisms, the buried $\mathrm{C}$ at depositional sites is not indefinitely stable and will be turned over and, slowly but steadily, released back to the atmosphere with a delay of decades to centuries.

Acknowledgements. This research is financed in the framework of the Action de Recherché Concertée (Convention no. 09/14-022) of the Communauté Française de Belgique. Further financial support has been given by: UC Louvain Fonds spécial de recherche (FSR), \& ETH Zurich Professorship for Sustainable Agroecosystems. K. Van Oost, J.-T. Cornelis, and S. Doetterl are research associates of the Fonds de la Recherche Scientifique (FNRS), Belgium. S. Doetterl and J.-T. Cornelis designed the research, S. Doetterl performed the research and analyzed the data, and all authors interpreted the data and wrote the paper.

Edited by: Y. Kuzyakov

\section{References}

Amelung, W., Miltner, A., Zhang, X., and Zech, W.: Fate of microbial residues during litter decomposition as affected by minerals, Soil Sci., 166, 598-606, 2001. 
Amelung, W., Brodowski, S., Sandhage-Hofmann, A., and Bol, R.: Combining biomarker with stable isotope analyses for assessing the transformation and turnover of soil organic matter, Adv. Agron., 100, 155-250, 2008.

Bascomb, C. L.: Distribution of pyrophosphate-extractable iron and organic carbon in soils of various groups, J. Soil Sci., 19, 251268, 1968.

Berhe, A. A., Harden, J. W., Torn, M. S., Kleber, M., Burton, S. D., and Harte, J.: Persistence of soil organic matter in eroding vs. depositional landform positions, J. Geophys. Res., 117, G02019, doi:10.1029/2011JG001790, 2012.

Bodé, S.: Development of a Compund Specific Stable Isotope Method for Amino Sugars as Tracers of Microbial Dynamics in Terrestrial Ecosystems, PhD thesis, Ghent University, Belgium, 206 pp., 2013.

Bodé, S., Denef, K., and Boeckx, P.: Development and evaluation of a high-performance liquid chromatography/isotope ratio mass spectrometry methodology for delta C-13 analyses of amino sugars in soil, Rapid Commun. Mass Sp., 23, 2519-2526, 2009.

Bossuyt, H., Denef, K., Six, J., Frey, S. D., Merckx, R., and Paustian, K.: Influence of microbial populations and residue quality on aggregate stability, Appl. Soil Ecol., 16, 195-208, 2001.

Brahy, V. and Delvaux, B.: Cation exchange resin and test vermiculite to study soil processes in situ in a toposequence of Luvisol and Cambisol on loess, Eur. J. Soil Sci., 52, 397-408, 2001.

Brindley, G. W. and Brown, G.: Crystal Structures of Clay Minerals and Their Identification, Mineralogical Society Monograph no. 5, Mineralogical Society, London, 495 pp., 1980.

Chao, T. T. and Sanzolone, R. F.: Decomposition techniques, J. Geochem. Explor., 44, 65-106, 1992.

Cotrufo, M. F., Wallenstein, M. D., Boot, C., Denef, K., and Paul, E.: The Microbial Efficiency- Matrix Stabilization (MEMS) framework integrates plant litter decomposition with soil organic matter stabilization: do labile plant inputs form stable soil organic matter?, Glob. Change Biol., 19, 988-995, 2012.

Cui, J., Li, Z., Liu, Z., Ge, B., Fang, C., Zhou, C., and Tang, B.: Physical and chemical stabilization of soil organic carbon along a 500 year cultived soil chronosequence originating from estuarine wetlands: temporal patterns and land use effects, Agr. Ecosyst. Environ., 196, 10-20, 2014.

Dahlgren, R. A.: Quantification of allophane and imogolite, in: Quantitative methods in soil mineralogy, edited by: Zelazny, L. W. and Amonette, J. E., Soil Science Society of America, Madison, 430-451, 1994.

Denef, K., Six, J., Bossuyt, H., Frey, S. D., Eliott, E. T., Merckx, R., and Pasutian, K.: Influence of dry-wet cycles on the interrelationship between aggregate, particulate organic matter, and microbial community dynamics, Soil Biol. Biochem., 33, 15991611,2001

Dlugoss, V.: Impacts of Soil Redistribution Processes on Soil Organic Carbon Stocks and Fluxes in a Small Agricultural Catchment, $\mathrm{PhD}$ thesis, Geographisches Institut der Universität zu Köln, Köln, 143 pp., 2011.

Doetterl, S., Six, J., VanWesemael, B., and Van Oost, K.: Carbon cycling in eroding landscapes, geomorphic controls on soil organic C pool composition and C stabilization, Glob. Change Biol., 18, 2218-2232, 2012.

Duemig, A., Smittenberg, R., and Koegel-Knabner, I.: Concurrent evolution of organic and mineral components during initial soil development after retreat of the Damma glacier, 5 Switzerland, Geoderma, 163, 83-94, 2011.

Duemig, A., Haeusler, W., Steffens, M., and Koegel-Knabner, I.: Clay fractions from a soil chronosequence after glacier retreat reveal the initial evolution of organo-mineral associations, Geochim. Cosmochim. Ac., 85, 1-18, 2012.

Dungait, J. A. J., Hopkins, D. W., Gregory, A. S., and Whitmore, A. P.: Soil organic matter turnover is governed by accessibility not recalcitrance, Glob. Change Biol., 18, 1781-1796, 2012.

Eusterhues, K., Rumpel, C., and Koegel-Knabner, I.: Organomineral associations in sandy acid forest soils, importance of specific surface area, iron oxides and micropores, Eur. J. Soil Sci., 56, 753-763, 2005.

Eusterhues, K., Wagner, F. E., Haeusler, W., Hanzlik, M., Knicker, H., Totsche, K. U., Koegel-Knabner, I., and Schwertmann, U.: Characterization of ferrihydrite-soil organic matter coprecipitates by $X$ ray diffraction and Mössbauer spectroscopy, Environ. Sci. Technol., 42, 7891-7897, 2008.

Fan, Y., Lei, T., and Cai, Q.: Effects of wetting rate on soil surface strength and aggregate stability, Transactions of the Chinese Society of Agricultural Engineering, 24, 46-50, 2008.

Gibbs, R. J.: The geochemistry of the Amazon River system. Part I. The factors that control the salinity and the composition and concentration of the suspended solids, Bull. Geol. Soc. Am., 78, 1203-1232, 1967.

Glaser, B. and Gross, S.: Compound-specific delta C-13 analysis of individual amino sugars - a tool to quantify timing and amount of soil microbial residue stabilization, Rapid Commun. Mass Sp., 19, 1409-1416, 2005

Glaser, B., Turrion, M. B., and Alef, K.: Amino sugars and muramic acid - biomarkers for soil microbial community structure analysis, Soil Biol. Biochem., 36, 399-407, 2004.

Goldberg, S.: Interaction of aluminium and iron oxides and clay minerals and their effect on soil physical properties: a review, Commun. Soil Sci. Plan., 20, 1181-1207, 1989.

Guggenberger, G., Frey, S. D., Six, J., Paustian, K., and Elliott, E. T.: Bacterial and fungal cell-wall residues in conventional and no-tillage agroecosystems, Soil Sci. Soc. Am. J., 63, 1188-1198, 1999.

Harden, J. W., Sharpe, J. M., Parton, W. J., Ojima, D. S., Fries, T. L., Huntington, T. G., and Dabney, S. M.: Dynamic replacement and loss of soil carbon on eroding cropland, Global Biogeochem. Cy., 13, 885-901, 1999.

Helgason, B. I., Konschu, H. J., Bedard-Haughn, A., and VandenBygaart, A. J.: Microbial distribution in an eroded landscape: buried A horizons support abundant and unique communities, Agr. Ecosyst. Environ., 196, 94-102, 2014.

Herbillon, A. J.: Chemical estimation of wheatherable minerals present in the diagnostic horizons of low activity clay soils, in: Proceedings of the eighth international soil classification workshop - Classification, Characterization and Utilization of Oxisols, Part 1 - Papers, edited by: Beinroth, F. H., Camargo, M. N., and Eswaran, H., Rio de Janeiro, 12 to 23 May 1986, 39-48, 1988.

Huang, P. M., Wang, T. S. C., Wang, M. K., Wu, M. H., and Hsu, N. W.: Retention of phenolic acids by noncrystalline hydroxyaluminum and -iron compounds and clay minerals of soils, Soil Sci., 123, 213-219, 1977. 
Hoffmann, T., Schlummer, M., Notebaert, B., Verstraeten, G., and Korup, O.: Carbon burial in soil sediments from Holocene agricultural erosion, Central Europe, Global Biogeochem. Cy., 27, 828-835, doi:10.1002/gbc.20071, 2013.

Kaiser, K. and Guggenberger, G.: Mineral surfaces and soil organic matter, Eur. J. Soil Sci., 54, 219-236, 2003.

Kaiser, K. and Zech, W.: Defects in estimation of aluminum in humus complexes of podzolic soils by pyrophosphate extraction, Soil Sci., 161, 452-458, 1996.

Kleber, M.: What is recalcitrant soil organic matter?, Environ. Chem., 7, 320-332, 2010.

Kleber, M., Mikutta, R., Torn, M. S., and Jahn, R.: Poorly crystalline mineral phases protect organic matter in acid subsoil horizons, Eur. J. Soil Sci., 56, 717-725, 2005.

Kodama, A. and Schnitzer, M.: Effects of fulvic acids on the crystallization of aluminum hydroxides, Geoderma, 24, 195-205, 1980.

IRM: Climatogramm for the Period 1961-1990, Station 06447 (Uccle; Belgique), retrieved 28 July 2011, available at: http://www.recordmeteo.com/weather-hi-low/ weather-station-duccle-en-6447.html (last access: 25 November 2014), 2011.

Johnson, W. C.: Carbon cycle: sequestration in buried soils, Nat. Geosci., 7, 398-399, 2014.

Kolb, S. E., Fermanisch, K. J., and Dornbush, M. E.: Effect of charchoal 5 quantity on microbial biomass and activity in temperate soils, Soil Sci. Soc. Am. J., 7, 1173-1181, 2009.

Lannoo: Le grand Atlas de Ferraris, Lannoo, 600 pp., 2009.

Lindsay, W. L. (Ed.): Chemical equilibria in soils, The Blackburn Press, West Caldwell, USA, 450 pp., 1979.

Mehra, O. P. and Jackson, M. L.: Iron oxide removal from soils and clays by a dithionite - citrate system buffered with sodium bicarbonate, Clay. Miner., 5, 317-327, 1960.

Mikutta, R., Schaumann, G. E., Gildemeister, D., Bonneville, S., Kramer, M. G., Chadwick, O. A., and Guggenberger, G.: Biogeochemistry of mineral-organic associations across a long-term mineralogical soil gradient (0.3-4100 kyr), Hawaiian Islands, Geochim. Cosmochim. Ac., 73, 234-260, 2009.

Muneer, M. and Oades, J. M.: The role of Ca-organic interactions in soil aggregate stability. III. Mechanisms and models, Aust. J. Soil Res., 27, 411-423, 1989.

Park, J.-H., Meusburger, K., Jang, I., Hojeong, K., and Alewell, C.: Erosion-induced changes in soil biogeochmical and microbiological properties in Swiss Alpine grasslands, Soil Biol. Biochem., 69, 382-392, 2014.

R Development Core Team: R, a Language and Environment for Statistical Computing, R Foundation for Statistical Computing, available at: http://www.r-project.org (last access: 28 July 2014), 2010.

Robert, M. and Tessier, D.: Méthode de préparation des argiles des sols pour des études minéralogiques, Annals Agronomiques, 25, 859-882, 1974 (in French).

Roberts, P., Bol, R., and Jones, D. L.: Free amino sugar reactions in soil in relation to soil carbon and nitrogen cycling, Soil Biol. Biochem., 39, 3081-3092, 2007.

Rommens, T., Verstraeten, G., Poesen, J., Govers, G., Van Rompaey, A., Peeters, I., and Lang, A.: Soil erosion and sediment deposition in the Belgian loess belt during the Holocene, establishing a sediment budget for a small agricultural catchment, Holocene, 15, 1032-1043, 2005.
Salomé, C., Nunan, N., Pouteau, V., Lerch, T. Z., and Chenu, C.: Carbon dynamics in topsoil and in subsoil may be controlled by different regulatory mechanisms, Glob. Change Biol., 16, 416426, 2010.

Schmidt, M. W. I., Torn, M. S., Abiven, S., Dittmar, T., Guggenberger, G., Janssens, I. A., Kleber, M., Koegel-Knabner, I., Lehmann, J., Manning, D. A. C., Nannipieri, P., Rasse, D. P., Weiner, S., and Trumbore, S. E.: Persistence of soil organic matter as an ecosystem property, Nature, 478, 49-56, 2011.

Schuppli, P. A., Ross, G. J., and McKeague, J. A.: The effective removal of suspended materials from pyrophosphate extracts of soils from tropical and temperate regions, Soil Sci. Soc. Am. J., 47, 1026-1032, 1983.

Simpson, R. T., Frey, S. D., Six, J., and Thiet, R. K.: Preferential accumulation of microbial carbon in aggregate structures of notillage soils, Soil Sci. Soc. Am. J., 68, 1249-1255, 2004.

Six, J., Elliott, E. T., Paustian, K., and Doran, J. W.: Aggregation and soil organic matter accumulation in cultivated and native grassland soils, Soil Sci. Soc. Am. J., 62, 1367-1377, 1998.

Six, J., Conant, R. T., Paul, E. A., and Paustian, K.: Stabilization mechanisms of soil organic matter, implications for C-saturation of soils, Plant Soil, 241, 155-176, 2002.

Sollins, P., Homann, P., and Caidwell, B. A.: Stabilization and destabilization of soil organic matter: mechanisms and controls, Geoderma, 74, 65-105, 1996.

Stucki, J. W., Goodman, B. A., and Schwertmann, U.: Iron in Soils and Clay Minerals, Springer, Dordrecht, 893 pp., 1988.

Stuiver, M. and Polach, H. A.: Discussion - reporting of ${ }^{14} \mathrm{C}$ data, Radiocarbon, 19, 355-363, 1977.

Van Oost, K., Verstraeten, G., Doetterl, S., Notebaert, B., Wiaux, F., Broothaerts, N., and Six, J.: Legacy of human-induced C erosion and burial on soil-atmosphere C exchange, P. Natl. Acad. Sci. USA, 109, 19492-19497, doi:10.1073/pnas.1211162109, 2012.

Van Ranst, E., De Coninck, F., Tavernier, R., and Langohr, R.: Mineralogy in silty to loamy soils of central and high Belgium in respect to autochthonous and allochthonous materials, Bulletin de la Société Belge de Géologie, 91, 27-44, 1982.

von Luetzow, M. and Koegel-Knabner, I.: Response to the concept paper: What is recalcitrant soil organic matter?, by Markus Kleber, Environ. Chem., 57, 333-335, 2010.

von Luetzow, M., Koegel-Knabner, I., Ekschmitt, K., Matzner, E., Guggenberger, G., Marschner, B., and Flessa, H.: Stabilization of organic matter in temperate soils, mechanisms and their relevance under different soil conditions - a review, Eur. J. Soil Sci., 57, 426-445, 2006.

Wang, X., Cammeraat, L. H.,Wang, Z., Zhou, J., Govers, G., and Kalbitz, K.: Stability of organic matter in soils of the Belgian Loess Belt upon erosion and deposition, Eur. J. Soil Sci., 64, 219-228, 2013.

Wang, X., Cammeraat, E. L. H., Cerli, C., and Kalbitz, K.: Soil aggregation and the stabilization of organic carbon as affected by erosion and deposition, Soil Biol. Biochem., 72, 55-65, 2014.

Wang, Z., Govers, G., Steegen, A., Clymans, W., Van den Putte, A., Langhans, C., Merckx, R., and Van Oost, K.: Catchment-scale carbon redistribution and delivery by water erosion in an intensively cultivated area, Geomorphology, 124, 65-74, 2010.

Wang, Z., Van Oost, K., Lang, A., Quine, T., Clymans, W., Merckx, R., Notebaert, B., and Govers, G.: The fate of buried organic car- 
bon in colluvial soils: a long-term perspective, Biogeosciences, 11, 873-883, doi:10.5194/bg-11-873-2014, 2014.

Wiaux, F., Cornelis, J.-T., Cao, W., Vanclooster, M., and Van Oost, $\mathrm{K}$.: Combined effect of geomorphic and pedogenic processes on the distribution of soil organic carbon quality along an eroding hillslope on loess soil, Geoderma, 214, 36-47, 2014a.

Wiaux, F., Vanclooster, M., Cornelis, J.-T., and Van Oost, K.: Factors controlling soil organic carbon persistence along an eroding hillslope in the loess belt, Soil Biol. Biochem., 77, 187-196, 2014b.

Wouters, L. and Vandenberghe, N.: Géologie de la Campine, Essai de synthèse, ONDRAF, Brussels, 1994.
Xu, X., Trumbore, S. E., Zheng, S., Southon, J. R., McDuffee, K. E., Luttgen, M., and Liu, J. C.: Modifying a sealed tube zinc reduction method for preparation of AMS graphite targets: reducing background and attaining high precision, Nucl. Instrum. Meth. B, 259, 320-329, 2007.

Yu, H., Ding, W., Luo, J., Geng, R., Ghani, A., and Cai, Z.: Effects of long-term compost and fertilizer application on stability of aggregate-associated organic carbon in an intensively cultivated sandy loam soil, Biol. Fert. Soils, 48, 325-336, doi:10.1007/s00374-011-0629-2, 2011.

Yoo, K., Amundson, R., Heimsath, A. M., and Dietrich,W. E.: Spatial patterns of soil organic carbon on hillslopes: integrating geomorphic processes and the biological $\mathrm{C}$ cycle, Geoderma, 130, 47-65, 2006 